\title{
MONTANA DEPARTMENT OF FISH, WILDLIFE AND PARKS FISHERIES DIVISION JOB PROGRESS REPORT
}

\author{
STATE: Montana
}

Project No.: $\underline{F-78-R-3}$

PROJECT TITLE: Statewide Fisheries Investigations

JOB TITLE: Missouri River Pallid Sturgeon Inventory

Period Covered: July 1, 1996 through June 30, 1997

\section{ABSTRACT}

STATE DOCUMENTS COLLECTION

$$
\ldots \cup \cup 2003
$$

MONTANA STATE LIBRARY 1515 E. 6th AVE. HELENA MONTANA 59620

A study to evaluate the reintroduction of the pallid sturgeon in the upper Missouri River and determine the effects on the Marias River fishery resulting from a new flow regime below Tiber Dam was continued. A total of 4 pallid sturgeon were captured, two of these paliids were "new" fish. A total of $8,552 \mathrm{fish}$ were sampled in the lower Marias River and the adjacent confluence area of the Missouri River and shorthead redhorse and goldeye comprised $51 \%$ of the total. Sauger spring catch rates in the Marias confluence area have declined from an average of $18.6 \mathrm{fish} / \mathrm{hr}$ for the period 197988 compared to $3.1 \mathrm{fish} / \mathrm{hr}$ measured this year.

\section{INTRODUCTION}

Pallid sturgeon are found in the Wild and Scenic portions of the Missouri River in Montana. They exist in low numbers throughout their geographic range (Kallemeyn 1983) as is the case in this section of the Missouri River. In 1990 the U.S. Fish and Wildlife Service listed the pallid as endangered under the Endangered Species Act 1973. Reasons for listing are habitat modification and apparent lack of reproduction. Reports of pallid sturgeon sightings have also declined dramatically in the last 20 years (U.S. Fish and Wildlife Service, 1989). The pallid sturgeon has been listed as a class A "species of special concern" in Montana since 1973 (Holton, 1980).

The Montana Department of Fish Wildlife and Parks (FWP) has studied the Upper Missouri River population for 6 years and have concluded that the population is endangered of going extinct within 10-20 years unless immediate actions are taken. Several years of study shows that only about 50 adult pallids remain and that the population is senescent. Moreover, there was no evidence of successful reproduction at least in the last 10 years. 
The recovery plan calls for reintroducing pallid in this area as a short term remedy with the anticipation that hatchery reared fish will eventually reproduce and maintain a reasonable population (Dryer and Sandvol 1993). Considering this information the original study objectives were modified to evaluating the success of the pallid sturgeon reintroduction.

The lower Marias River downstream of Tiber Dam is completely regulated by the operations of the dam. At the FWP request, the $U$. S. Bureau of Reclamation (USBR), which manages Tiber, recently agreed to provide an annual spring pulse of high water from the dam to provide more natural spring flow conditions for the aquatic system downriver. It is believed this action will benefit both the resident and migratory fisheries. The Pallid sturgeon Recovery Plan identified the need to implement operational alternatives for tributary dams that will emulate precontrol hydrographs so that seasonal habitat conditions are restored for pallid sturgeon and other native big river fishes (1.1.2 and 2.2.2) (Dryer and Sandvol 1993). The lower Marias River study was initiated in the spring, 1996 to evaluate the effects these higher spring flows were having on the fisheries in the area.

\section{OBJECTIVES AND DEGREE OF ATTAINMENT}

1. Develop a systematic standardized sampling plan for evaluating the success of reintroducing pallid sturgeon in the study area. A plan was devised and the first standardized survey was completed and results are presented.

2. Radio tag juvenile shovelnose sturgeon and monitor their habitat use and movement patterns. Six sturgeon were radio tagged and results are presented.

3. Evaluate the effects of high springtime flow releases from Tiber Reservoir on migratory warm and coolwater fish spawning success in the Marias River and determine fish population response in adjacent areas of the Missouri River. Electrofishing, drift netting and larval fish sampling were completed in 3 sections of the lower Marias and 2 sections in the Missouri River and results are presented.

4. Identify limiting factors and attempt to improve coldwater fish populations in the Marias River immediately downstream from Tiber Reservoir. A standing crop population estimate was completed this year and results are presented in another report $(\mathrm{F}-78-\mathrm{R}-3$ Northcentral Montana Coldwater Streams). 
5. Review projects proposed by state, federal and local agencies and private parties which have the potential to affect fisheries resources and aquatic habitats. Provide technical advice or decisions to reduce or mitigate resource damage. The final draft was completed recommending guidelines for the operation of Tiber Dam to benefit the fisheries resources. Provided comments for the draft pallid sturgeon stocking plan. Prepared information on the Missouri River warmwater fishery for the state warmwater fish plan.

\section{PROCEDURES}

An electrofishing system was used to sample fish in the river. The system was a dual boom-type and mounted to a 17-foot aluminum boat powered by a $90 \mathrm{hp}$ outboard jet motor. Power was supplied by a 4,000-watt $A C$ generator. The alternating current was delivered to a coffelt Model VvP-10 rectifying unit which changes the alternating current to pulsed-DC. The positive electrode setup consisted of two fiberglass booms with 4,18 inch pieces of stainless steel cable attached to each boom that extended from the end of the boom and into the water. The boat hull served as the negative. The unit was typically operated at 2-7 amps, 100-215 volts. Catch per unit effort for electrofishing was expressed as number of fish caught per hour. Electrofishing was not used for capturing pallid sturgeon, nor was this method used in areas of known pallid sturgeon concentrations.

Trammel nets were also used to capture fish. Trammel nets used for pallid sturgeon sampling were $150 \mathrm{ft}$. Iong and $6 \mathrm{ft}$. deep and $100 \times 6 \mathrm{ft}$. for all other sampling. Two mesh sizes were used: 1 inch inner walls with 10 inch outer walls, and 2 inch inner walls with 10 inch outer walls. Mesh material for both inner and outer walls were light-weight for better fish tangle characteristics and to insure that the net could be retrieved off submerged objects in the event that net material had to be torn free. The trammel nets were set in snag-free areas of the river and allowed to drift with the current along the bottom for a period of 3-7 minutes. Distances of the drift varied from 50 to 400 yds. Catch per unit effort for drift netting was expressed as number of fish caught per drift.

All fish were measured to the nearest 0.1 inch (fork length for sturgeon and total length for all other fish), and weighed to the nearest 0.01 pound. Blue suckers were tagged with a PIT tag, sturgeon with a plastic cinch tag and sauger and walleye with a metal monel jaw tag. A spiny dorsal fin ray was extracted from sauger and walleye for aging purposes. 
Larval fish sampling was used to evaluate spawning use in the Marias, Missouri and Teton rivers. Larval samples were obtained using boat mounted round plankton net samplers. The round samplers consisted of a 6 foot long Nitex net $(750$ micron mesh) attached to a 20 inch diameter metal ring. Two nets were used in tandem so that duplicate samples could be taken simultaneously. The nets had a 3-rope harness that were fastened to and suspended off a weighted line attached to each side of the bow of the boat. Samples were collected near the channel bottom and surface while drifting slightly downstream. This allowed the nets to filter the water without addition of excess weights. Most of the sampling occurred in strong current areas of the river, at a depth range of 3-12 feet, and therefore power was provided by an outboard motor to decrease the downstream drift rate. The nets were positioned and weighted in the river usually for a duration of $6 \rightarrow 15$ minutes, depending on the amount of debris suspended in the river. The volume of water filtered was determined using General oceanic flow meters (Model 2030) tied to the front ring of the net and positioned at one-third of the net diameter.

Larval samples were preserved with formalin in the field and later sorted in the laboratory. Larvae were identified to family using taxonomic keys by Auer (1982) and Wallus (1990).

A radio telemetry system was used to follow and re-locate blue suckers and juvenile shovelnose sturgeon. A low frequency band receiver along with omni-directional and directional antennas were used to make contact with the transmittered fish. An internal transmitter with the antenna protruding out of the body cavity was surgically implanted into the sturgeon's body cavity. Surgical procedures used are previously described by Gardner (1994). The 10 gram transmitter was 2 inches long with a 0.4 inch diameter and had a 90-day battery life.

The other type of transmitter used was considerably smaller and included a microprocessor so the radio was transmitting for only 6 hours a day, for 20 days, and then completly off for 20 days. This on/off pattern would repeat itself until the battery would expire, which was about 90 days. These mini-transmitters were surgically implanted into the body cavity of small shovelnose sturgeon weighing approximately 1 lb. The 2.4 gram transmitter was 0.8 inches long with a 0.2 inch diameter and had an external whip antenna 8 inches long. These methods of transmitter attachments have been successfully used by several other researchers including Tyus (1988).

A $6 \mathrm{ft}$. wide, beam "rockhopper" trawl was used for sampling young-of-the-year (YOY) sturgeon. The trawl consists of a $6 \times 1 \frac{1}{2}$ ft. rectangular metal frame with skids, $18 \mathrm{ft}$. long outer chafing net with an $11 \mathrm{ft}$. long, 1/8 inch mesh inner liner. The trawl was towed downstream off the bow of the boat usually for a distance of 150-200 yds. A $50 \mathrm{ft}$. length of rope was attached to each side of the trawl and at the end the run the trawl was retrieved by hand by a person at the end of each rope. This was a scaled-down version of the trawl used by the white sturgeon researchers in the lower Columbia River (Lance Beckman, USFWS). 


\section{DESCRIPTION OF STUDY AREA}

The pallid sturgeon study area consists of a 175 mile reach of the mainstem middle Missouri River in northcentral Montana between Fort Benton and the headwaters of Fort Peck Reservoir near Lewistown. There are two major tributaries entering the Missouri in this reach; the Marias River from the north and Judith River from the south. The present flow regimen of the Missouri River in the study area is not entirely natural because of regulation and storage at several upriver dams.

The Marias River fisheries study area consists of a 80 mile reach of the lower Marias River from the confluence with the Missouri upriver to Tiber Dam near Chester, Montana. The Teton River is the only major tributary entering the Marias, joining the Marias only one mile upriver from the Marias/Missouri confluence. The present flow regimen of the Marias River in the study area is completly regulated by Tiber Dam.

Sampling was conducted at 3 study sections on the Marias and 2 study sections on the Missouri River. These 5 sections are Pondera, Black Coulee, Confluence, Upper Missouri and Lower Missouri and are shown in Figure 1. All 5 study sections were each 4 miles long.

\section{FINDINGS}

The Missouri River experienced above normal run-off during the 1996 field season. The average monthly flows for May, June and July, 1996 were 116, 179 and $130 \%$ of normal (USGS 1997 and DNRC 1991). The peak flow of 30,200 cfs occurred on June 12 and was slightly above normal for spring peak flows in the upper Missouri. Early-spring, summer and fall flows in 1996 were also well above normal conditions.

\section{Pallid sturgeon}

A sampling plan was developed for evaluating the success of pallid sturgeon reintroduction in the study area. The plan requires sampling a designated 17 mile reach from RM 13 to RM 30 (Rock Creek to Upper Two Calf). This was designated as the sampling reach because this is where the majority of pallid observations in the past 6 years have been recorded, especially in the fall. It was assumed that a total of 50 trammel net drifts would be an adequate effort to survey the reach for pallid sturgeon. 
Figure 1. Map of the Marias River study area.

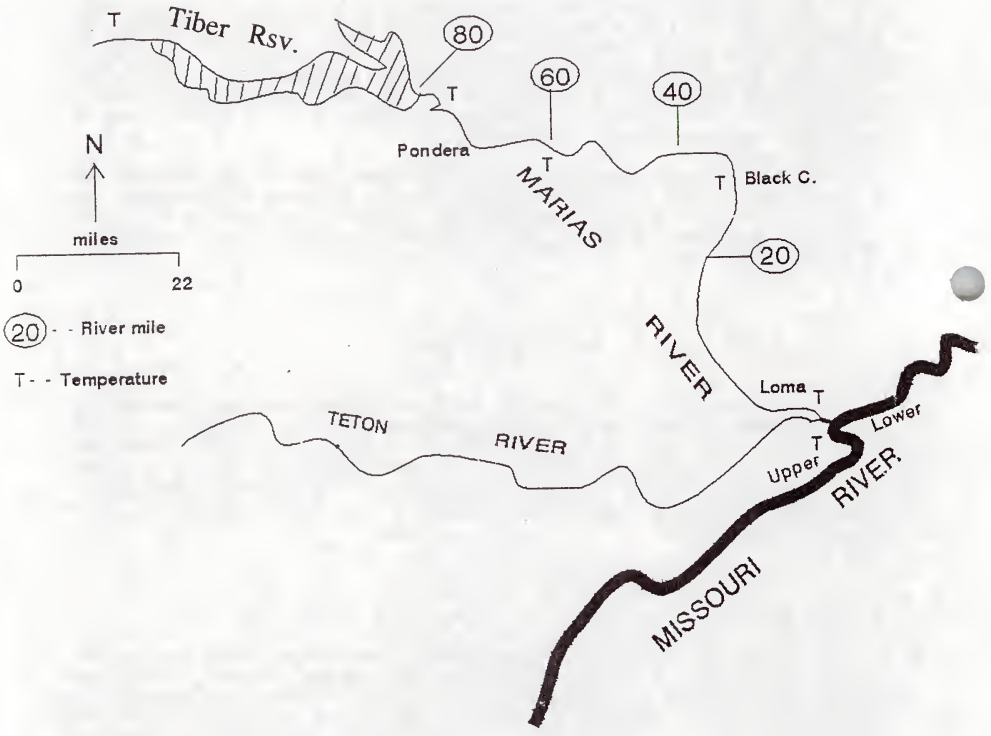


Selection of drift sites was determined using a stratified-random process. The reach was divided into $170,0.2-\mathrm{mile}$ sites. A total of 30 sampling sites were randomly drawn reach-wide, and an additional 20 sites were selected based on records of previous pallid sturgeon captures at the site. These sites were sampled during the period $9 / 23-10 / 01$.

A total of 3 pallid sturgeon were captured during the survey. An additional 4 th pallid was captured on August 14 while drift netting for juvenile shovelnose sturgeon. The statistics for these $\mathrm{fish}$ are given in Appendix A. All 4 pallids were most Iikely older fish based on their sizes. Two of the 4 pallids were new fish, raising the total to 30 different pallid sturgeon captured in the study area since the study began in 1990. Statistics for the survey:

\author{
Number of pallids/drift $=0.06$ \\ Number of pallids/minute of drift $=0.009$ \\ Number of pallids/distance (yards) drifted $=0.0002$ \\ Number of shovelnose/drift $=4.5$ \\ Number of shovelnose/minute of drift $=0.71$ \\ Average drift duration $=6.3$ minutes \\ Average drift distance $=239 \mathrm{yd}$ \\ Average depth of drift site $=7.1 \mathrm{ft}$
}

\title{
Juvenile shovelnose sturgeon radio telemetry
}

The radio telemetry study determining habitat preferences and movement patterns of juvenile sturgeon was continued this year. Juvenile shovelnose sturgeon were telemetered and used as a surrogate species for pallid sturgeon because no juvenile pallids were captured. A total of 6 shovelnose, ranging in size from 0.28 - 1.75 lbs., were surgically implanted with a 2.5 gram transmitter and monitored during the period $7 / 25$ - 10/21. Only 16 relocations were made on these fish because of either the difficulty capturing the fish resulting in a delayed start, or difficulty detecting the fish in deep water. The relocations for individual fish are given in Appendix B. Of the 6 sturgeon transmittered, 3 fish were relocated at least 3 times; 2 sturgeon appeared to have died (based on their stationary location for several weeks and/or their location in shallow depositional areas); and one could not be located after 3 weeks.

The 3 telemetered sturgeon, number's 21, 640 and 660 , moved downstream an average of 9.8 miles from their release sites. Generally, the greatest downriver move occurred within the first week after they were implanted with the transmitter and released, after which, they remained in a localized area. Eight habitat measurements were taken on these three fish and are given in Table 1. The sturgeon were found in deep/swift current areas that averaged $8.7 \mathrm{ft}$ deep, with a current velocity of $2.4 \mathrm{ft} / \mathrm{s}$. 
Table 1. Habitat conditions at sites where 3 transmittered juvenile shovelnose were located, upper Missouri

River, 1996.

\begin{tabular}{|c|c|c|c|c|c|c|}
\hline Fish\# & Date & $\begin{array}{l}\text { Water Col } \\
\text { Depth } \\
\text { (ft) }\end{array}$ & $\begin{array}{l}\text { Relative* } \\
\text { Depth }\end{array}$ & $\begin{array}{c}\text { Water Col. } \\
\text { Avg Velcty } \\
(\mathrm{ft} / \mathrm{s})\end{array}$ & Substr & $\begin{array}{c}\text { Habitat } \\
\text { Assoc }\end{array}$ \\
\hline 621 & $9 / 4$ & 8.0 & 73 & 2.4 & sand & MCRn** \\
\hline 621 & $9 / 12$ & 9.7 & 97 & 2.0 & sand & MCRn \\
\hline 640 & $9 / 5$ & 11.0 & 76 & 2.3 & sand & MCRn \\
\hline 640 & $9 / 12$ & 10.2 & 82 & 2.2 & sand & MCRn \\
\hline 660 & $9 / 4$ & 9.5 & 81 & 2.8 & sand & MCRn \\
\hline 660 & $9 / 5$ & 5.7 & 95 & 2.3 & sand & MCRn \\
\hline 660 & $9 / 12$ & 6.4 & 55 & 2.3 & sand & MCRn \\
\hline 660 & $10 / 24$ & 9.2 & 100 & 2.6 & sand & MCRn \\
\hline Avg. & & 8.7 & 82 & 2.4 & & \\
\hline
\end{tabular}

* Relative depth = fish depth/maximum depth at cross-section expressed as a percentage.

** MCRn $=$ main channel run

The telemetry system appeared to work fairly well with the transmitters' signal being received in depths up to $15 \mathrm{feet}$. The two smallest sturgeon probably died resulting from complications with the surgical implants. Therefore, it is recommended that these transmitters be implanted in sturgeon no smaller than 0.50 lbs. A greater amount of tracking-time than was given for this study needs to be allocated for future work in order to get a more comprehensive description of sturgeon habitat preferences.

An attempt was made to locate sturgeon rearing areas. All the sampling effort was directed in the Robinson Bridge Section because it was felt the best opportunity to find young-of-year (YOY) sturgeon was in this area. Trawling was used for sampling a variety of deep open-water habitats in the river; likely areas for YOY sturgeon. A total of 57 hauls sampled $295 \mathrm{fish}$, representing at least 15 species (Table 2). Sicklefin chub was the most abundant species sampled. No YOY sturgeon were sampled in the trawl this year. 
Table 2. Numbers of small fish sampled with a benthic trawl in the Robinson Bridge Section, Missouri River, 1996. (Only fish less than 6 inches were included.)

\begin{tabular}{lccr}
\multicolumn{1}{c}{ Main Channel } & Main Channel & Total \\
\hline & Run & 1 & 1 \\
Burbot & 0 & 0 & 1 \\
Channel catfish & 1 & 8 & 13 \\
Flathead chub & 5 & 3 & 9 \\
Freshwater drum & 6 & 0 & 1 \\
Goldeye & 1 & 0 & 1 \\
Plains/silvery min & 1 & 1 & 3 \\
Longnose dace & 2 & 0 & 1 \\
River carpsucker & 1 & 2 & 4 \\
Sauger/walleye & 2 & 0 & 3 \\
Shorthead redhorse & 3 & 47 & 76 \\
Sicklefin chub & 39 & 0 & 7 \\
Stonecat & 7 & 25 & 9 \\
Sturgeon chub & 49 & 1 & 9 \\
Spottail shiner & 8 & 5 & 73 \\
Yellow perch & 4 & 49 & 295 \\
Unidentified & 24 & & 57 \\
Total catch & 153 & 21 &
\end{tabular}

\section{Marias River}

Flow conditions in the lower Marias River have changed substantially since the USBR began providing a spring high water pulse flow below Tiber Dam in 1994. Figure 2 is a comparison of the 1996 mean daily flows with that of flows prior to this change. It is fairly obvious that the lower Marias River now has a more natural flow pattern with higher peak flows occurring in June and lower base flows in late summer and fall. The 1996 peak flow of 3,307 cfs occurred on June 12 (USGS 1997) and was substantially lower than the estimated bankfull flow of 5,000 cfs for this reach. Early-spring, summer and fall flows were well above normal 
Figure 2. Marias River mean monthly flows downstream of

Tiber Dam prior to 1994 compared with 1994-96 (USGS water resource data, 1963-97).

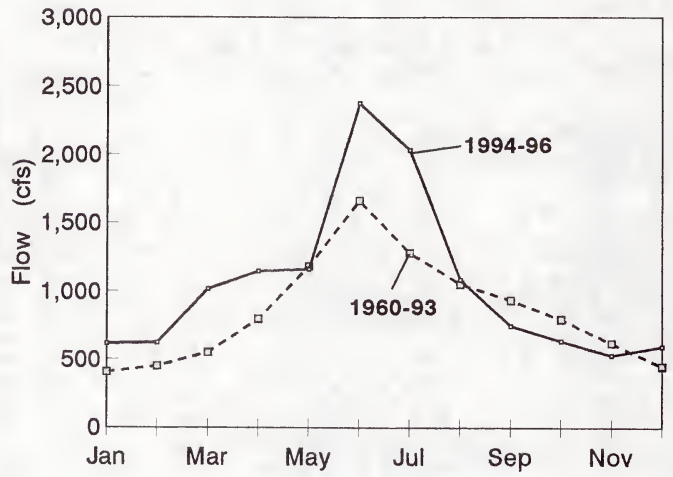

Temperature conditions.

Along with unnatural flow conditions, altered water temperature regimes are also a concern downstream of a large dam (Ward and Stanford 1979). Water temperatures were monitored at 6 sites and results are depicted in Figure 3. Temperature probes at two sites were lost (Marias River upstream of Tiber Reservoir and Missouri River upstream of confluence), therefore, comparisons can only be made between the 4 Marias River stations.

The upstream, Tiber and Circle Bridge stations were much cooler than the downstream Black Coulee and Confluence stations, April through August. Water temperatures for the warmer months of July and August Combined, averaged 56.6, 59.9, 63.9 and 66.0 fahrenheit degrees for Tiber, Circle, Black Coulee and Confluence, respectively. 
Figure 3. Marias River mean daily water temperatures for Tiber (RM 75.1), Circle (RM 57.9), Black Coulee (RM 28.5) and Confluence (RM 1.0) stations, 1996.
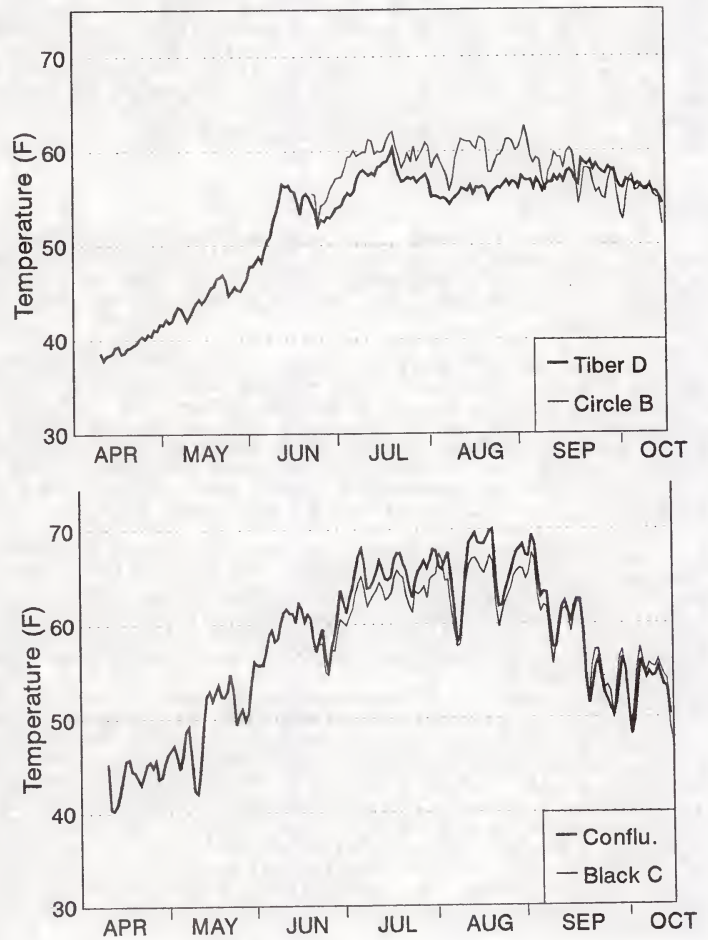
Daily mean temperatures at Confluence surpassed $60 \mathrm{~F}$ in early June and most of the month thereafter. This temperature is the minimum for several important migratory fish that may use the Marias River to spawn. Shovelnose sturgeon and paddlefish normally spawn during June in Montana (Berg 1981) and require temperatures of $60^{\circ} \mathrm{F}$ or greater (Wallus 1990). Pallid sturgeon probably have similar temperature requirements to the poaddlefish. It appears the Marias River at the Confluence had suitable temperatures for sturgeon and paddlefish spawning during 1996. Temperatures were not being monitored at the Black coulee station during most of June, but based on the similarity of the thermographs for both Black coulee and Confluence during the remainder of the monitored period it is likely that temperatures at Black Coulee were also suitable for sturgeon and paddlefish spawning.

Fish populations.

Significant changes in the Marias Rivers' flow and temperature regimes will most likely affect fish populations in the river. species abundance and distribution, along with use by migratory species for spawning, are the specific parameters that were investigated.

A total of 148 larval fish samples were collected during the period May 9 - July 18. Forty-eight samples were taken in the Confluence Section of the Marias River, 15 samples at the confluence of the Teton River, 38 samples in the Upper Missouri River Section, and 47 in the Lower Missouri River Section. This larval survey was conducted to determine timing location and incubation success of spawning fish. Results from the 1996 larval fish survey will be summarized in next years report.

A total of $8,552 \mathrm{fish}$ were sampled in the study area using electrofishing and netting methods, from April 17 - July 17, 1996. More effort was directed at electrofishing compared to drift netting because netting is more difficult and less productive in small shallow rivers like the Marias. Average sizes for the sampled fish are calculated for each study section and reported in Appendix $\mathrm{C}$ and $\mathrm{D}$.

Catch rates for electrofishing are given in Table 3 . Shorthead redhorse was a common species sampled at all Marias River stations, ranging in abundance from 12.1 to $68.3 \mathrm{fish} / \mathrm{hr}$. at Pondera and Confluence sections, respectively. Other species sampled at high catch rates in most of the areas were goldeye, river carpsucker and longnose sucker. Mountain whitefish were sampled at the high rate of $73.3 \mathrm{fish} / \mathrm{hr}$ in the upstream Pondera section. Mountain whitefish prefer cool clear water (Brown 1971) which is typical of the Pondera section. Water temperatures and turbidity increases in a downstream progression and the Marias River becomes more favorable for warmwater species in the lower 3 sections. 
Table 3. Average catch rates (no./hour) and number of fish sampled by electrofishing in the upper Missouri and Marias rivers, MT, 1996.

\begin{tabular}{|c|c|c|c|c|c|c|}
\hline & $\begin{array}{l}\text { Pondera } \\
\text { Coulee }\end{array}$ & $\begin{array}{l}\text { Black } \\
\text { Coulee }\end{array}$ & $\begin{array}{l}\text { Confl } \\
\text { uence }\end{array}$ & $\begin{array}{l}\text { Upper } \\
\text { Missouri }\end{array}$ & $\begin{array}{l}\text { Lower } \\
\text { Missouri }\end{array}$ & $\begin{array}{l}\text { Total } \\
\text { Number }\end{array}$ \\
\hline Bigmouth buffalo & 5.4 & 8.4 & 0.9 & 9.0 & 11.1 & 293 \\
\hline Blue Sucker & 0.7 & 0.5 & 1.5 & 0.2 & 0.8 & 52 \\
\hline Brown trout & 3.0 & 1.0 & 0.4 & 0.2 & 0.4 & 57 \\
\hline Burbot & & 0.2 & 0.5 & 0.1 & & 6 \\
\hline Carp & 8.8 & 7.1 & 6.8 & 9.6 & 16.6 & 595 \\
\hline Channel catfish & & & 0.1 & 0.2 & & 4 \\
\hline Cisco & & & & & 0.1 & 1 \\
\hline Freshwater drum & & 0.1 & 0.3 & 1.4 & 0.8 & 31 \\
\hline Goldeye & 1.2 & 34.0 & 27.8 & 29.6 & 62.5 & 2159 \\
\hline Longnose sucker & 4.4 & 12.5 & 12.0 & 4.2 & 7.8 & 598 \\
\hline Mountain whitefish & 73.3 & 9.6 & 5.0 & 1.2 & 1.4 & 949 \\
\hline Northern pike & 0.8 & 0.4 & 0.5 & 0.3 & 0.6 & 32 \\
\hline Rainbow trout. & 1.6 & 0.1 & & 0.1 & 0.4 & 22 \\
\hline River carpsucker & 1.6 & 5.9 & 21.1 & 9.6 & 13.6 & 762 \\
\hline Sauger & & 3.8 & 3.6 & 4.3 & 5.0 & 243 \\
\hline Shorthead redhorse & 12.1 & 49.7 & 68.3 & 16.0 & 7.5 & 1823 \\
\hline Shovelnose sturgeon & & 0.5 & 0.6 & 0.6 & 0.9 & 34 \\
\hline Smallmouth bass & & & 0.5 & 0.5 & 0.2 & 18 \\
\hline Smallmouth buffalo & 0.1 & 0.1 & & 2.7 & 1.2 & 34 \\
\hline Walleye & 0.8 & 1.5 & 1.8 & 2.0 & 1.8 & 98 \\
\hline White sucker & 4.4 & 3.6 & 2.6 & 1.3 & 0.4 & 166 \\
\hline Yellow perch & 0.1 & & 0.1 & & & 2 \\
\hline Total no. fish & 1075 & 2178 & 2233 & 1294 & 1064 & 7979 \\
\hline Total no. hours & 9.1 & 16.6 & 19.2 & 13.9 & 8.0 & 66.8 \\
\hline
\end{tabular}


Table 4. Average catch rates (no./drift) and number of fish sampled with trammel nets in the upper Missouri and Marias rivers, MT, 1996.

\begin{tabular}{|c|c|c|c|c|c|c|}
\hline & $\begin{array}{l}\text { Pondera } \\
\text { Coulee }\end{array}$ & $\begin{array}{l}\text { Black } \\
\text { Coulee }\end{array}$ & $\begin{array}{l}\text { Confl } \\
\text { uence }\end{array}$ & $\begin{array}{l}\text { Upper } \\
\text { Missouri }\end{array}$ & $\begin{array}{l}\text { Lower } \\
\text { Missouri }\end{array}$ & $\begin{array}{l}\text { Total } \\
\text { Number }\end{array}$ \\
\hline $\begin{array}{l}\text { Blue Sucker } \\
\text { Carp } \\
\text { Channel catfish } \\
\text { Goldeye } \\
\text { Largemouth buffalo } \\
\text { Longnose sucker } \\
\text { Mountain whitefish } \\
\text { River carpsucker } \\
\text { Sauger } \\
\text { Shorthead redhorse } \\
\text { Shovelnose sturgeon } \\
\text { White sucker }\end{array}$ & $\begin{array}{l}0.3 \\
2.4\end{array}$ & $\begin{array}{l}0.9 \\
0.2 \\
0.4 \\
0.5 \\
0.9 \\
0.1\end{array}$ & $\begin{array}{l}0.1 \\
0.1 \\
5.8 \\
\operatorname{tr} . \\
0.5 \\
0.1 \\
0.6 \\
\operatorname{tr} . \\
1.2 \\
0.5\end{array}$ & $\begin{array}{l}2.6 \\
0.1 \\
0.6\end{array}$ & $\begin{array}{l}2.2 \\
2.1 \\
0.4\end{array}$ & $\begin{array}{r}4 \\
6 \\
2 \\
318 \\
2 \\
73 \\
17 \\
25 \\
1 \\
62 \\
58 \\
5\end{array}$ \\
\hline Total no. fish & 63 & 126 & 215 & 61 & 108 & 573 \\
\hline Total no. sets & 11 & 14 & 24 & 16 & 14 & 79 \\
\hline
\end{tabular}


Catch rates for electrofishing in the two Missouri River sections indicate that fish populations in the Missouri are similar to the Marias River (Table 3). Goldeye were sampled at the greatest rate here, averaging $46.0 \mathrm{fish} / \mathrm{hr}$. Most of the other species sampled were found in both rivers with the exception of cisco being sampled only in the Missouri and yellow perch being sampled only in the Marias. There has previously been a record of cisco in the Confluence Section of the Marias River, (personal observation; May 9, 1988). Yellow perch has previously been recorded in the upper Missouri River where it was listed as an uncommon species (Berg 1981).

Trammel net drifting was carried out April 18 - July 16 and catch rates for all sections are reported in Table 4. Only about $7 \%$ of the total fish sampled by both methods were captured drifting nets. The most important information attained from sampling with the nets is the data collected on sturgeon. Only 34 shovelnose were sampled in 66.8 hours of electroshocking compared to a total of 58 captured in 79 trammel net drifts. Gardner (1991) reported that 1 and 2 inch trammel nets are especially effective at sampling fish in deep water and at capturing sturgeon. The highest catch rates of shovelnose were recorded in the Confluence Section of the Marias and the Lower Missouri River Section where they were caught at a rate of a little over 1 fish/net drifted.

Sauger, blue sucker, paddlefish, shovelnose and pallid sturgeon are 5 species of particular interest to this study. The sauger is a native game species that has declined in abundance over the last 10 years; blue sucker and paddlefish are state species of Special Concern; shovelnose sturgeon is a species sensitive to habitat alterations and over exploitation; and pallid sturgeon is a federally listed endangered species. All these species are known to migrate to the confluence area or up into the Marias River. Changes in Marias River flow conditions could affect the migratory use by these species.

Significant numbers of sauger from the Missouri River move upstream in the Marias to spawn (Berg 1981). This spawning run has been monitored in a $4-\mathrm{mile}$ trend area, intermittently over the past 18 years so that population abundance patterns can monitored. Table 5 summarizes the average catch rates and shows there has been a serious decline in numbers of sauger spawners in the trend area for the 1996 survey. Catch rates averaged $18.6 \mathrm{fish} / \mathrm{hr}$. for the six years of survey data prior to 1996 compared to an average catch rate of $3.1 \mathrm{fish} / \mathrm{hr}$. for 1996 . 
Table 5. Spring catch rates ( $\mathrm{CPUE}=\# / \mathrm{hr}$ ) of sauger electrofished in the Marias River - Confluence Section, 1979-96.

$\begin{array}{llllll}\begin{array}{l}\text { Date } \\ \text { CPUE }\end{array} & \frac{1979}{18.2} & & & \\ \begin{array}{l}\text { Date } \\ \text { CPUE }\end{array} & \frac{1982}{39.2} & \frac{1985}{12.3} & \frac{1986}{12.7} & \frac{1987}{16.5} & \frac{1988}{12.9} \\ \begin{array}{l}\text { Date } \\ \text { CPUE }\end{array} & \frac{1996}{3.1} & & & \end{array}$

Unfortunately, there is an eight year data gap between the last two years so it is difficult to know when the decline first occurred. Sauger abundance trends in the Missouri River 37 miles upstream near Great Falls may be representative of the population condition near the Marias and indicate abundance patterns representative of both areas. Past sauger catch rates for the Morony Section averaged $14.4,28.3$ and 13.8 for 1978,1979 and 1988 , respectively (Berg 1981 and Liknes et al. 1989). However, serious declines were first noticed in 1989 when the sauger catch rate fell to 2.3 and then averaged 2.0 sauger/hr from 1990-95 (Liknes et al. 1993 and 1994, and Hill et al. 1995 and 1996). It can be concluded that declines in sauger numbers first occurred in 1989 and have remained at low numbers since then. The specific reasons for this decline is unknown.

Berg (1981) found that the Marias River was a very important spawning area for sauger spawning. Changes in the Marias River flows resulting from the change in operation of Tiber Dam probably is not the cause of the sauger decline. Changes in operations were first initiated during the late spring, 1994, 5 years after the decline was first noticed. It is possible that cooler than normal spring water temperatures resulting from hypolimnion water releases from the dam may be making the Marias less suitable for sauger spawning. This factor is presently being evaluated and conclusions will be presented when an adequate number of years have been monitored.

A significant number of spawning blue suckers were found in the lower Marias during 1977-79 (Berg 1981). Berg also reported that a large number were sampled migrating up the Teton River, a tributary to the Marias. During 1996 we sampled 76 blue sucker in the Marias River; 27 were captured near the dam by the auxiliary outlet on June 12, and 31 were captured in the Confluence Section during several sampling occasions (Table 3 ). The remaining 18 were captured at points in between these two sections. 
Several blue sucker were observed in the Teton River during early May surfacing near rip-rap banks. This unusual behavior was believed to be associated with spawning activity.

Shovelnose sturgeon were also sampled in significant numbers during the spring, 1996 sampling season. A total of 46 were sampled in the Marias and were noted as far upstream as the Black Coulee section with the majority found in the confluence section (Table 3). Gardner and Berg (1983) reported finding shovelnose as far upstream as the Pondera Section, although in low numbers.

Paddlefish and pallid sturgeon were not sampled or observed in the Marias River during 1996. Brown (1971) reported paddlefish in the Marias River downstream of Tiber Dam probably in 1964. There has been several unconfirmed paddlefish observations since then, the most recent being reported by USBR Tiber Dam personnel in 1977. Pallid sturgeon have not been reported in the vicinity of the Marias since 1964. The more recent (1990), farthest upriver sighting occurred in the Missouri River near stafford Ferry, 80 miles downriver from the Marias confluence.

An additional $438 \mathrm{fish}$ were sampled in the Robinson Bridge Section of the Missouri River using trammel nets and this data is reported in Appendix $\mathrm{E}$.

Blue sucker radio telemetry.

Little is known about the blue sucker populations in the upper Missouri River. Blue sucker are most easily sampled during their spawning period in May and June, after which, they are infrequently captured. Radio telemetry was used so that blue sucker could be monitored throughout the summer and more information on movement patterns and habitat use could be obtained.

A total of 4 blue suckers, ranging in weight from $5.7-8.1$ 1b., were surgically implanted with 10 gram transmitters and monitored during the period June 14 - October 31. Twenty-three relocations were made on these fish (Appendix F). All of the transmittered fish appeared to be moving freely and no abnormal behavior, characteristic of an injured fish, was noticed. All 4 fish were electrofished in or near the confluence area of the Marias and Missouri rivers.

Three of the $4 \mathrm{blue}$ suckers moved downriver an average of 38 miles from the release site in to a canyon area where the river is typically wide, shallow with cobble and boulder substrates. The one remaining fish initially moved upriver into the Teton River, 5 miles upstream, where it was relocated twice during the last 8 days of May. This fish was later found in the Missouri River, 7 miles downstream from the confluence, where it remained in a localized area for 72 days. Seven habitat measurements were taken at blue sucker relocation sites and are given in Table 6 . 
Table 6. Habitat conditions at sites where 4 transmittered blue suckers were located, upper Missouri River, 1996.

\begin{tabular}{lcccccr} 
Fish\# & Date & $\begin{array}{c}\text { Water Col } \\
\text { Depth } \\
(\mathrm{ft})\end{array}$ & $\begin{array}{c}\text { Percent } \\
\text { Max Depth }\end{array}$ & $\begin{array}{c}\text { Water Col. } \\
\text { Avg Velcty } \\
\text { (ft/s) }\end{array}$ & Substr & $\begin{array}{c}\text { Habitat } \\
\text { Assoc }\end{array}$ \\
\hline 559 & $7 / 31$ & 2.4 & 40 & 2.6 & cobl & MCRf* \\
559 & $9 / 20$ & 5.6 & 100 & 2.4 & gvl & MCRn** \\
691 & $8 / 28$ & 4.2 & 60 & 1.0 & gvl & Eddy \\
730 & $9 / 19$ & 4.3 & 83 & 2.0 & gvl & MCRf \\
750 & $7 / 9$ & 8.0 & 100 & 2.8 & h.pan & MCRn \\
750 & $7 / 30$ & 4.7 & 72 & 3.9 & cobl & MCRf \\
750 & $9 / 19$ & 5.3 & 71 & 2.4 & gvl & MCRn \\
-90 & 4.9 & 75 & 2.4 & &
\end{tabular}

* MCRf $=$ main channel riffle; ** MCRn = main channel run.

The blue suckers were found in somewhat shallow, fast current areas, having gravel to cobble channel substrates. These habitat conditions are fairly typical of the Missouri River canyon area.

\section{RECOMMENDATIONS}

1. Continue with the pallid sturgeon reintroduction effort. This includes systematic standardized sampling for adults, biannually, beginning 1997. Young hatchery reared pallids stocked in the upper Missouri River should be closely monitored so that the results of the stocking program can be immediately evaluated. Radio telemetry methodology should be used for this evaluation.

2. Continue with the lower Marias River fisheries study, evaluating the effects of providing more natural high spring flows from Tiber Dam.

3. The sauger population in the upper Missouri River has experienced a serious decline in numbers. Population studies should be initiated to determine the reasons and the extent of the decline. Management actions for improving their numbers should be devised 


\section{ACKNOWLEDGEMENTS}

Randy Rodencal, Brian Haugen and Darren Johnson assisted with all aspects of fish sampling and data collection. Their efforts are greatly appreciated.

\section{LITERATURE CITED}

Auer, N.A., editor. 1982. Identification of larval fishes of the Great Lakes basin with emphasis on the Lake Michigan drainage. Great Lakes Fishery Commission Special Publication 82-3, Ann Arbor, MI.

Berg, R. K. 1981. Fish populations of the Wild and Scenic Missouri River, Montana. Mont. Dept. of Fish, Wildlife \& Parks. Helena. Fed. Aid to Fish \& Wildlife Rest. Proj. FW-3R. Job Ia. $242 \mathrm{pp}$.

Brown, C.J.D. 1971. Fishes of Montana. Big Sky Books, MSU, Bozeman, MT 207pp.

Dryer, M. P. and A. J. Sandvol. 1993. Recovery plan for the pallid sturgeon (Scaphirhynchus albus). U S Fish and Wildlife Service. Bismarck, ND. $55 \mathrm{pp}$.

Gardner, W.M. and R. K. Berg. 1983. Instream flow requirements for the Marias River fishery downstream of Tiber Dam. Mont. Dept. Fish, Wildlife \& Parks. Helena.

- 1991. Northcentral Montana Fisheries Study, Missouri River Pallid sturgeon Inventory. Mont. Dept. of Fish, Wildlife \& Parks. Helena. Fed. Aid to Fish and Wildilfe Rest. Proj. F-46-R-4. Study No. III, Job D. 13pp.

1994. Northcentral Montana Fisheries Study, Missouri River Pallid Sturgeon Inventory. Mont. Dept. of Fish, Wildlife and Parks. Helena. Fed. Aid to Fish and Wildilfe Rest. Proj. F-46-R-7. Study No. III, Job D. $16 \mathrm{pp}$.

Hill, William J., George A. Liknes, Anne Tews and Paul Hamlin. 1995. Statewide fisheries investigations, Northcentral Montana warm and coolwater ecosystems. Mont. Dept. of Fish Wildlife and Parks. Helena. Fed. Aid to Fish and Wildlife Rest. Proj. F-78-R-1. 31 pp. 
., George A. Liknes, Anne Tews and Paul Hamlin. 1996. Statewide fisheries investigations, Northcentral Montana warm and coolwater ecosystems. Mont. Dept. of Fish Wildlife and Parks. Helena. Fed. Aid to Fish and Wildlife Rest. Proj. F-78-R-2. $31 \mathrm{pp}$.

Holton, G. 1980. The riddles of existence: fishes of "special concern". Montana Outdoors 11(1): $26 \mathrm{pp}$.

Kallemeyn, L.W. 1983. Status of the pallid sturgeon(Scaphirhynchus albus). Fisheries $8(1): 3-9$.

Liknes, George A., William J. Hill and Stephen A. Leathe. 1989. Statewide fisheries investigations, Northcentral Montana warmwater streams investigations. Mont. Dept. of Fish Wildlife and Parks. Helena. Fed. Aid to Fish and Wildlife Rest. Proj. F-46-R-2. $3 \mathrm{pp}$.

- and William J. Hill. 1993. Statewide fisheries investigations, Northcentral Montana warmwater streams investigations. Mont. Dept. of Fish Wildlife and Parks. Helena. Fed. Aid to Fish and Wildlife Rest. Proj. F-46-R-6. $3 \mathrm{pp}$.

- and William J. Hill 1994. Statewide fisheries investigations, Northcentral Montana warmwater streams investigations. Mont. Dept. of Fish Wildlife and Parks. Helena. Fed. Aid to Fish and Wildlife Rest. Proj. F-46-R-7. 3 pp.

Montana Dept. of Natural Resc. and Conservation. 1991. Missouri Basin, environmental impact statement for water reservation applications above Fort Peck Dam. Helena. 435 pp.

Tyus, H.M. 1988. Acquisition of habitat preference data by radio telemetry. In: K.D. Bovee and J.L. Zuboy (editors). 1988. Proceedings of a workshop on the development and evaluation of habitat suitability criteria. USFWS, Biological Report 88 .

U.S. Fish and Wildlife Service. 1989. Endangered and threatened wildlife and plants; rule to list the pallid sturgeon as an endangered species. Federal Register. Vol. 55, No. 173. pp 36641 - 36647 .

U.S. Geological Service. 1997. Water Resources for Montana. Helena.

Wallus, R. 1990. Reproductive biology and early life history of fishes in the Ohio River Drainage. Volume 1. Tennessee Valley Authority. Chattanooga, TN. 273 pp. 
Ward, J. V. and J. A. Stanford (eds.). 1979. The Ecology of Regulated Streams. Plenum Press, New York. 398 pp.

Prepared by: William M. Gardner

Date:

December, 1997 
Appendix A. Measurements and capture information for pallid sturgeon sampled in the upper Missouri River, MT, 1996.

\begin{tabular}{|c|c|c|c|c|}
\hline$\dot{.}$ & $-\cdots-\cdots-\cdots$ & -- Pallid & geon & ------ \\
\hline Tag Number & 8472317830 & 17600296132 & 34354641585 & G-01352 \\
\hline Fk Length (in.) & 54.0 & 55.5 & 55.5 & 55.0 \\
\hline Weight (1b.) & 33.0 & 41.0 & 38.5 & 37.8 \\
\hline Sex & -- & -- & - & -- \\
\hline Capture Date & Aug 14 & Sep 24 & Sep 25 & Sep 27 \\
\hline Rivermile & 21.4 & 27.5 & 22.0 & 19.0 \\
\hline Method & Net & Net & Net & Net \\
\hline Depth (ft) & 6.5 & 6.0 & 12.0 & 7.0 \\
\hline Velocty. (fps) & Moderate & Moderate & Moderate & Moderate \\
\hline Substrate & Sand & Sand & Sand & Sand \\
\hline Temperature & 74 & 53 & 54 & 50 \\
\hline Secchi (ft) & 2.3 & 1.2 & 2.0 & 2.0 \\
\hline Recap Record & new & new & Tagged 5/6/92 & Tagged $7 / 10 / 91$ \\
\hline
\end{tabular}


Appendix B. Locations of radio transmittered juvenile shovelnose sturgeon monitored in the upper Missouri River, 1996.

\# 610

$\mathrm{FL}=12.3$ in. $\mathrm{WT}=0.28 \mathrm{lb}$.

\#021 $\begin{aligned} & \mathrm{FL}=23.3 \mathrm{in} . \mathrm{WT}=1.751 \mathrm{~b} . \\ & \text { Release } \mathrm{RM} 25.0 \text { on } 8 / 30\end{aligned}$

contact 1. $9 / 4$ e RM 24.1

Contact 2. $9 / 5$ e RM 24.1

contact 3. $9 / 12$ e RM 16.8

\# 620

$F L=13.2$ in. $\quad W T=0.28 \quad \mathrm{lb}$.

contact 1. $9 / 11$ e RM -7.0 suspected mortality.

\# 640

$\mathrm{FL}=21.1$ in. $\quad \mathrm{WT}=1.25 \mathrm{lb}$.

contact 1. $9 / 5$ @ RM 5.4

contact 2. $9 / 10$ @ RM 5.4 Suspected mortality.

$\# 660$

Release @ RM 21.3 on $7 / 26$

contact 1. $9 / 5$ e RM 11.0

Contact 2. $9 / 9$ a RM 10.8

contact 3. $9 / 12$ @ RM 11.0

\# 710

$F L=20.8 \mathrm{in.} \quad W T=1.35 \mathrm{lb}$.

Release @ RM 16.7 on $7 / 25$

contact 1. 7/26 e RM 16.7

$F L=19.2$ in. $\quad W T=1.051 b$.

contact 1. 9/4 @ RM 19.5

contact 2. 9/5 e RM 16.1

contact 3. 9/9 e RM 13.9

Contact 4 . $9 / 12$ e RM 15.6

contact 5. 10/24 @ RM 14.2

contact 2 . $8 / 13$ e RM 6.5 
Appendix Table c. Summary size statistics for fish sampled with electrofishing in the upper Missouri and Marias rivers, MT, 1996.

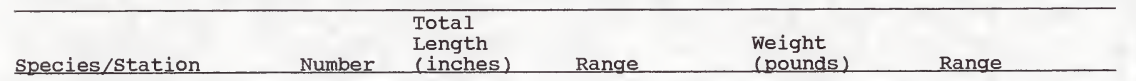

Blue sucker

Tiber

Pondera $\mathrm{C}$.

Black C.

Confluence

Upper Missouri

Lower Missouri

Brown trout

Pondera C.

Black C.

Sheep $C$.

Confluence

Upper Missouri

Lower Missouri

Carp

Tiber

Pondera $\mathrm{C}$.

Black C.

Sheep C.

Confluence

Upper Missouri

Lower Missouri

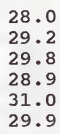

$(25.6-31.5)$

$(27.9-31.1)$

$(27.2-32.3)$

$(23.5-33.4)$

$(28.5-34.2)$

$(27.9-31.7)$

6.20
8.00
7.90
7.90
9.50
8.30

$(4.70-9.40)$

$(6.60-10.20)$

$(6.50-10.00)$

$(3.50-11.80)$

$(7.20-12.50)$

$(5.90-10.20)$

$$
\begin{aligned}
& (6.5-23.7) \\
& (5.8-19.5) \\
& (10.6-21.1 \\
& (5.0-10.5) \\
& (5.2-7.3) \\
& (5.3-10.6)
\end{aligned}
$$

16.2

7.8

6.6

7.7
1.40
1.00
1.60
0.20
0.10
0.20

$(0.10-4.30)$

$(0.20-2.10)$

$(0.50-2.80)$

$(0.10-0.40)$

$(0.10-0.20)$

$(0.10-0.50)$

1
80
90
13
95
63
127

21.9
20.7
20.4
20.4
21.0
22.2
21.9

$(14.1-26.3)$
$(12.8-26.7)$
$(18.0-24.2)$
$(11.4-26.5)$
$(12.4-27.0)$
$(17.3-27.0)$

5.10

4.30

4.20

4.20

4.60

5.40

5.30

$$
\begin{aligned}
& (1.50-8.80) \\
& (1.30-9.50) \\
& (2.90-6.90) \\
& (0.70-10.30) \\
& (1.10-9.60) \\
& (2.50-10.50)
\end{aligned}
$$


Appendix Table c. (continued)

Channel catfish

Confluence

Upper Missouri

Cisco

Lower Missouri

Freshwater drum

Black c.

Confluence

Upper Missouri

Lower Missouri

Goldeye

Pondera C.

Black C.

Sheep C.

Confluence

Upper Missouri

Lower Missouri

29.8

18.4

$\left(16.5^{--} 20.0\right)$

10.90

2.20

$(1.40-3.30)$

13.1

$$
--
$$

0.60

12.8

13.6

13.1

13.2

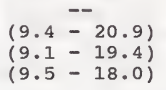

1.00

1.60

1.20

1.20

$(0.40-4.40)$

$(0.50-3.90)$

$(0.40-2.90)$

Largemouth buffalo

Pondera C.

Black C.

Sheep C.

Confluence

Upper Missouri

Lower Missouri
12.4
12.2
12.3
12.5
12.2
12.1

$$
\begin{aligned}
& (11.8-14.0) \\
& (10.7-14.7) \\
& (11.0-14.2) \\
& (11.4-16.0) \\
& (10.9-16.5) \\
& (10.8-14.2)
\end{aligned}
$$

0.60

0.65

0.62

0.65

0.60

0.60

$$
\begin{aligned}
& (0.50-1.00) \\
& (0.40-1.00) \\
& (0.50-0.90) \\
& (0.45-1.30) \\
& (0.40-1.88) \\
& (0.43-1.00)
\end{aligned}
$$

$\begin{array}{rr}4 & 30.8 \\ 6 & 32.1 \\ 1 & 31.3 \\ 13 & 29.3 \\ 12 & 31.8 \\ 19 & 30.8\end{array}$

$\begin{array}{cc}(28.9-33.4) & 13.75 \\ (28.8-40.5) & 16.29 \\ -- & 15.00 \\ (26.0-35.3) & 15.26 \\ (29.0-42.0) & 17.59 \\ (26.6-35.5) & 16.49\end{array}$

$(7.50-15.50)$

$(13.80-28.4)$

$\left(10.60^{--}-27.00\right)$

$(8.90-30.00)$

$(10.90-28.00)$ 
Appendix Table C. (continued)

Ling

\begin{abstract}
Black C.
Sheep C.
\end{abstract}

Confluence

$\begin{array}{ll}3 & 17.3 \\ 1 & 24.0 \\ 1 & 21.0\end{array}$
$(10.8-20.9)$
$--$

Longnose sucker

Pondera c.

Black C.

Sheep C.

confluence

Upper Missouri

Lower Missouri

$\begin{array}{rr}40 & 14.5 \\ 105 & 13.1 \\ 21 & 16.3 \\ 124 & 13.8 \\ 42 & 13.4 \\ 62 & 12.9\end{array}$

$$
\begin{aligned}
& (4.3-20.0) \\
& (4.1-18.3) \\
& (5.7-19.0) \\
& (5.4-19.7) \\
& (3.9-19.7) \\
& (7.1-19.6)
\end{aligned}
$$

$$
\begin{aligned}
& 1.63 \\
& 1.16 \\
& 2.05 \\
& 1.35 \\
& 1.24 \\
& 1.05
\end{aligned}
$$

$$
\begin{aligned}
& (0.10-3.23) \\
& (0.04-2.55) \\
& (0.06-2.86) \\
& (0.10-3.20) \\
& (0.01-2.95) \\
& (0.17-2.95)
\end{aligned}
$$

Mountain whitefish

Pondera
Black C.
Sheep C.
Confluence
Upper Missouri
Lower Missouri

$\begin{array}{rr}125 & 11.8 \\ 66 & 13.0 \\ 50 & 12.0 \\ 96 & 13.9 \\ 14 & 15.2 \\ 11 & 14.2\end{array}$

$$
\begin{aligned}
& (5.0-18.6) \\
& (5.6-18.8) \\
& (6.1-19.3) \\
& (5.6-19.7) \\
& (7.9-18.6) \\
& (9.4-18.0)
\end{aligned}
$$

$$
\begin{aligned}
& 0.70 \\
& 0.98 \\
& 0.82 \\
& 1.35 \\
& 1.58 \\
& 1.35
\end{aligned}
$$

$$
\begin{aligned}
& (0.30-2.40) \\
& (0.50-2.83) \\
& (0.11-2.50) \\
& (0.10-2.90) \\
& (0.28-3.05) \\
& (0.35-2.34)
\end{aligned}
$$

Northern Pike

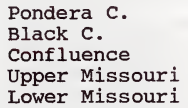

$\begin{array}{ll}7 & 22.5 \\ 7 & 25.7 \\ 9 & 25.0 \\ 4 & 25.8 \\ 5 & 27.7\end{array}$

3.38
4.02
3.52
3.92
5.19

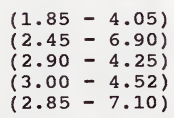


Appendix Table c. (continued)

Rainbow trout

Pondera $\mathrm{C}$.

Black C.

Sheep C.

Upper Missouri

Lower Missouri

River carpsucker

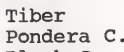

Black C.

Sheep C.

Confluence

Upper Missouri

Lower Missouri

Sauger

Black C.

Sheep C.

Confluence

Upper Missouri

Lower Missouri

Shorthead redhorse

Pondera
Black C.
Sheep C.
Confluence
Upper Missouri
Lower Missouri

$\begin{aligned} 10.5 & (5.1-16.5) \\ 12.1 & (7.1-17.1) \\ 10.4 & (5.0-14.1) \\ 14.2 & (9.1-19.3) \\ 9.7 & (4.1-15.2)\end{aligned}$

0.63

0.95

0.61

1.36

0.54

$$
\begin{aligned}
& (0.50-1.70) \\
& (0.16-1.75) \\
& (0.06-1.03) \\
& (0.32-2.40) \\
& (0.01-1.23)
\end{aligned}
$$

\subsection{5}

2.93

3.10

3.33

3.48

3.73

3.57

$$
\begin{aligned}
& (3.65-6.06) \\
& (2.05-5.80) \\
& (1.23-8.30) \\
& (2.00-6.04) \\
& (0.42-7.16) \\
& (1.06-8.10) \\
& (1.40-6.55)
\end{aligned}
$$

$(13.0-25.1)$
$(14.7-23.4)$

1.15

1.45

0.96

1.06

$(14.4-21.0)$

$(10.0-27.7)$

$(9.9-23.0)$

0.82

$(0.30-3.40)$

$(0.92-2.22)$

$(0.20-3.00)$

$(0.39-8.45)$

14.8
14.0

$(0.29-3.70)$

16.9

17.6

16.6

16.6

16.6

15.6
2.18

2.24

1.80

2.18

2.13

1.79

$$
\begin{aligned}
& (1.34-3.30) \\
& (0.95-4.15) \\
& (18.5-2.36) \\
& (0.05-4.50) \\
& (0.02-4.20) \\
& (0.50-3.60)
\end{aligned}
$$


Appendix Table c. (continued)

Shovelnose sturgeon *

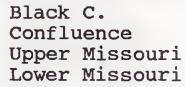

29.6

30.8

$(28.2-31.5)$

$(25.8-34.7)$

5.37

$(26.8-37.6)$

5.89

5.95

$(3.65-9.30)$

32.1

$(23.0-3.58)$

5.77

31.6

$(2.70-10.40)$

$(2.35-7.40)$

Smallmouth Bass

\section{Confluence \\ Upper Missouri}

Lower Missouri

$$
\begin{array}{r}
12.4 \\
9.5 \\
12.1
\end{array}
$$

$$
\begin{aligned}
& (10.5-14.0) \\
& (5.8-15.2) \\
& (10.1-14.0)
\end{aligned}
$$$$
1.06
$$

0.88

1.15

$$
\begin{aligned}
& (0.43-1.65) \\
& (0.20-2.60) \\
& (0.60-1.70)
\end{aligned}
$$

Smallmouth buffalo

$$
\begin{aligned}
& \text { Pondera C. } \\
& \text { Black C. } \\
& \text { Upper Missouri }
\end{aligned}
$$

Lower missouri

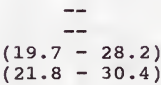

6.00

11.00

8.03

$$
\begin{aligned}
& (4.80-14.50) \\
& (5.47-17.00)
\end{aligned}
$$

8.60

Walleye

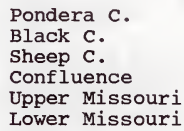

$\begin{array}{rr}7 & 15.6 \\ 25 & 16.8 \\ 6 & 17.8 \\ 24 & 16.6 \\ 28 & 13.4 \\ 14 & 14.1\end{array}$

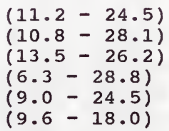
1.59
1.79
2.06
2.13
0.97
0.98


Appendix Table C. (continued)

White sucker

$\begin{array}{llllll}\text { Pondera } & 40 & 14.5 & (4.6-17.7) & 1.61 & (0.10-2.52) \\ \text { Black C. } & 56 & 12.4 & (6.0-16.8) & 0.97 & (0.11-2.12) \\ \text { Sheep C. } & 26 & 14.8 & (4.1-19.3) & 1.68 & (0.04-3.15) \\ \text { Confluence } & 49 & 10.3 & (4.9-15.2) & 0.64 & (0.10-1.60) \\ \text { Upper Missouri } & 18 & 11.5 & (5.8-17.4) & 1.05 & (0.11-2.57)\end{array}$

$\begin{array}{lllll} & \\ 3 & 12.2 & (10.9-14.2) & 0.84 & (0.55-1.30)\end{array}$

Yellow perch

$\begin{array}{lrrrrr}\text { Pondera C. } & 1 & 7.3 & -- & 0.25 & -- \\ \text { Confluence } & 1 & 10.2 & -- & 0.60 & --\end{array}$

* Shovelnose sturgeon length measurement is a fork length. 
Appendix Table D. Summary size statistics for fish sampled with trammel nets in the upper Missouri and Marias rivers, MT, 1996.

\begin{tabular}{lllll}
\hline & $\begin{array}{l}\text { Total } \\
\text { Length } \\
\text { Species/Station }\end{array}$ Number & Weight \\
(inches) & Range & (pounds) & Range \\
\hline
\end{tabular}

Bigmouth buffalo

$\begin{array}{llllll}\text { Confluence } & 1 & 33.7 & -- & 27.0 & - \\ \text { Upper Missouri } & 1 & 30.7 & - & 15.0\end{array}$

Blue sucker

Confluence

Upper Missouri

$2 \quad 28.0$

$2 \quad 27.6$

$(26.5-29.5)$

7.6

6.0

$(5.7-9.6)$

carp

Black Coulee

Upper Missouri

Lower Missouri

$\begin{array}{ll}1 & 20.3 \\ 1 & 27.4\end{array}$

$\begin{array}{ll}1 & 22.8\end{array}$

Channel catfish

Confluence

2

$14 \cdot 3$

$(13.8-14.8)$

1.23

$(0.86-1.60)$

Goldeye

Black Coulee

Confluence

Upper Missouri.

Lower Missouri

$\begin{array}{ll}40 & 12.0 \\ 22 & 12.1 \\ 10 & 11.9 \\ 17 & 12.1\end{array}$

0.55

0.54

0.53

0.57
$(0.41-0.72)$

$(0.40-0.65)$

$(0.43-0.67)$

$(0.45-0.70)$ 
Appendix Table D. (continued)

Longnose sucker

Pondera $\mathrm{C}$.

Black C.

Confluence

Upper Missouri

Lower Missouri

Mountain whitefish

\section{Pondera}

Black. C.

Confluence

River carpsucker

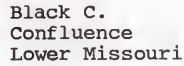

Lower Missouri

$\begin{array}{rr}6 & 18.4 \\ 11 & 19.5 \\ 5 & 21.0\end{array}$

18.4
19.5
21.0

$$
\begin{aligned}
& (16.4-21.1) \\
& (16.8-23.3) \\
& (18.5-23.8)
\end{aligned}
$$

$(17.5-19.4)$
$(11.5-18.8)$

$(9.5-16.9)$

$(8.9-19.3)$

15.1

14.7

$(9.4-19.2)$

2.60

1.76

1.18

1.66

1.42

$(2.30-3.15)$

$(0.65-2.64)$

$(0.40-1.85)$

$(0.36-3.20)$

$(0.35-2.75)$

0.34

0.58

$(0.22-0.46)$

11.2

$(8.8-12.7)$

1.71

$(0.29-0.80)$

$(14.0-18.1)$

2.88

3.39

4.38

$(2.05-3.70)$

$(2.10-5.42)$

$(2.90-4.60)$

Sauger

Confluence

1

15.1

Shorthead redhorse

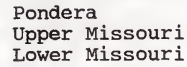

$\begin{array}{rr}1 & 18.2 \\ 1 & 12.8 \\ 16 & 14.8\end{array}$

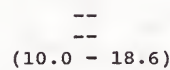

2.50
0.87
1.42
0.90
$(0.50-2.40)$ 
Appendix Table D. (continued)

Shovelnose sturgeon *

$\begin{array}{lrllll}\text { Black C. } & 13 & 29.5 & (25.0-34.4) & 4.83 & (2.50-9.05) \\ \text { Confluence } & 13 & 30.2 & (26.0-33.1) & 5.32 & (2.80-7.60) \\ \text { Upper Missouri } & 5 & 34.6 & (29.2-39.1) & 7.41 & (5.15-9.70) \\ \text { Lower Missouri } & 26 & 31.8 & (23.1-3.73) & 6.29 & (1.70-9.45)\end{array}$

White sucker

$\begin{array}{llllll}\text { Pondera } & 3 & 17.1 & (16.1-17.6) & 2.23 & (1.65-2.53) \\ \text { Black C. } & 2 & 12.9 & (8.9-16.8) & 1.20 & (0.40-1.99)\end{array}$

* Shovelnose sturgeon length measurement is a fork length. 
Appendix E. Locations of radio transmittered blue suckers monitored in the upper Missouri River, 1996.

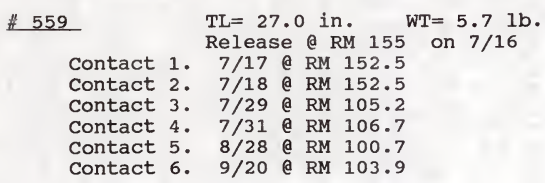

\# 691

$\mathrm{TL}=28.2$ in. $\quad \mathrm{WT}=6.3 \mathrm{lb}$.

Contact 1. $7 / 29$ @ RM 127.0

Contact 2. 7/30 e RM 119.1

Contact $3.8 / 28$ e RM 118.5

\# 730

$\mathrm{TL}=29.6 \mathrm{in} . \quad \mathrm{WT}=8.11 \mathrm{~b}$.

Release @ RM 0.5 (Marias R.) on $5 / 15$

contact 1. $6 / 7$ a RM 139.5 (Missouri R.)

Contact 2. 7/29 @ RM 115.0

contact 3 . 8/28 e RM 122.9

contact 4. 9/19 @ RM 123.7

contact 5. 10/31 @ RM 125.3

$\# 750$

$\mathrm{TL}=26.5 \mathrm{in.} \quad \mathrm{WT}=5.7 \mathrm{lb}$.

Release @ RM 0.5 (Marias R.) on $5 / 14$

contact 1. 5/24 \& Teton R. RM 5.0

contact 2. 5/31 e Teton R. RM 2.6

contact 3. $6 / 7$ @ RM 151.5 (Missouri R.)

Contact $4.7 / 9$ a RM 145.6

contact 5. 7/29 @ RM 145.7

contact $6.7 / 30$ e RM 145.8

Contact 7. $8 / 28$ e RM 149.0

Contact 8. $9 / 19$ e RM 148.9

Contact 10. 10/31 @ RM 138.7 
Appendix Table F. Summary size statistics for fish sampled with trammel nets in the Robinson Bridge section of the Missouri River, Mt, 1996.

\begin{tabular}{|c|c|c|c|c|c|c|}
\hline Species & Number & $\begin{array}{l}\text { Ttl Lngth } \\
\text { (inches) }\end{array}$ & Range & $\begin{array}{l}\text { Weight } \\
\text { (pounds) }\end{array}$ & \multicolumn{2}{|c|}{ Range } \\
\hline Blue sucker & 1 & 13.5 & -- & 0.62 & -- & \\
\hline Burbot & 1 & 12.0 & -- & 0.95 & -- & \\
\hline Carp & 16 & 20.3 & $(16.5-25.0)$ & 3.89 & $(2.39$ & $-7.10)$ \\
\hline Channel Catfish & 10 & 14.6 & $(9.9-19.0)$ & 1.19 & $(0.38$ & $-2.55)$ \\
\hline Freshwater Drum & 5 & 12.1 & $(11.5-12.6)$ & 0.84 & $(0.60$ & $-0.95)$ \\
\hline Goldeye & 70 & 11.4 & $(0.76-15.1)$ & 0.57 & $(0.15$ & $-1.30)$ \\
\hline Largemouth buffalo & 1 & 38.0 & -- & 32.50 & & -- \\
\hline Longnose sucker & 3 & 13.4 & $(10.8-15.6)$ & 1.13 & $(0.57$ & $-1.60)$ \\
\hline Pallid sturgeon & 4 & 54.9 & $(51.5-55.50$ & $35 \cdot 50$ & $(33.00$ & -41.201 \\
\hline River carpsucker & 17 & 18.2 & $(13.1-23.6)$ & 2.90 & $(1.20$ & $-5.60)$ \\
\hline Sauger & 7 & $17 \cdot 3$ & $(11.4-20.80$ & 1.84 & $(0.45$ & $-2.80)$ \\
\hline Shorthead redhorse & 16 & 11.8 & $(0.9-18.0)$ & 0.87 & $(0.20$ & $-2.30)$ \\
\hline Shovelnose sturgeon * & 285 & 26.2 & $(11.9-40.0)$ & 3.44 & $(0.20$ & $-13.0)$ \\
\hline Smallmouth buffalo & 4 & 26.5 & $(24.2-31.1)$ & 9.14 & $(7.40$ & $-11.50)$ \\
\hline Walleye & 2 & 20.9 & $(19.6-22.2)$ & 3.72 & $(2.90$ & $-4.55)$ \\
\hline
\end{tabular}

* Shovelnose sturgeon length measurement is fork length. 